\title{
Immunocytochemical and biochemical detection of alpha-L-fucosidase in Trypanosoma cruzi
}

\section{L.C. Miletti, M. Almeida-de-Faria, W. Colli and M.J.M. Alves}

Departamento de Bioquímica, Instituto de Química, Universidade de São Paulo, São Paulo, SP, Brasil

\author{
Correspondence \\ M.J.M. Alves \\ Departamento de Bioquímica \\ Instituto de Química, USP \\ Av. Lineu Prestes, 748 \\ Caixa Postal 26077 \\ 05513-970 São Paulo, SP \\ Brasil \\ Fax: +55-11-3815-5579 \\ E-mail: mjmalves@iq.usp.br \\ Part of a Master's thesis presented \\ by L.C. Miletti to the Institute of \\ Chemistry, University of São Paulo, \\ São Paulo, SP, Brazil. Research \\ supported by FAPESP (No. 99/12459-9 \\ to M.J.M. Alves and W. Colli). \\ L.C. Miletti was the recipient of a \\ fellowship from $\mathrm{CNPq}$.
}

Received November 13, 2002 Accepted January 31, 2003

\begin{abstract}
The aim of the present study was to demonstrate the presence of $\alpha$-Lfucosidase in Trypanosoma cruzi. Immunocytochemical and biochemical techniques were used to localize and characterize a membrane-associated, neutral-pH-optimum, $\alpha$-L-fucosidase from the parasite. Light and electron microscopy localized the $\alpha$-L-fucosidase specifically on the surface of the parasite and on membranes in the posterior region of the epimastigote stage. Although much less intense, labeling was also detected on the surface of trypomastigotes. At least $50 \%$ of the $\alpha$-L-fucosidase activity was associated with epimastigote membrane solubilized with $1 \mathrm{M} \mathrm{NaCl}$ or $1 \%$ Triton X-100, suggesting that $\alpha$-L-fucosidase is peripherally associated with membranes. The enzyme from epimastigotes had a neutral $\mathrm{pH}$ optimum (near 7) but displayed low specific activity when $p$-nitrophenyl- $\alpha$-Lfucoside was employed as substrate $(0.028 \mathrm{U} / \mathrm{mg}$ protein for epimastigotes and $0.015 \mathrm{U} / \mathrm{mg}$ protein for tissue culture-derived trypomastigotes). Polyacrylamide gel electrophoresis and Western blotting analysis both showed an expected 50-kDa polypeptide which was immunoreactive with anti- $\alpha$-L-fucosidase antibodies.
\end{abstract}

\section{Introduction}

Glycoconjugates from pathogens have been isolated and characterized due to their importance in a variety of biological functions. In the particular case of Trypanosoma cruzi, a protozoan parasite causing Chagas' disease, the most abundant surface glycoconjugates are a family of glycoinositolphospholipids (formerly lipopeptidophosphoglycan) with $2 \times 10^{7}$ molecules per parasite and a family of glycosylphosphatidylinositolanchored mucin-like glycoproteins with $2 \mathrm{x}$ $10^{6}$ molecules per parasite, both forming a coat that almost covers the entire surface of
Key words

- Trypanosoma cruzi

- Trypanosomatids

- Fucosidase

- Fucose

- Glycoproteins

- Glycolipids the parasite (1). Although much less abundant, many other important surface glycoconjugates have been described in epimastigotes (a noninvasive and replicative form) and trypomastigotes (an invasive and nonreplicative form) of $T$. cruzi. In particular, two glycoproteins at least contain $\alpha$-L-fucose in their structure: Gp-72, a glycoprotein isolated from epimastigote forms $(2,3)$, suggested to be involved in $T$. cruzi differentiation (4), and the trypomastigote stage-specific glycoproteins (5-7) belonging to the Tc-85 family and implicated in parasite-host cell adhesion (8-10). Glycopeptides isolated from Gp-72 by affinity chromatography contain 
rhamnose, fucose, xylose and galactose (1:1:2:3) linked to the peptide by a less usual phosphodiester linkage (11). Interestingly, no $\alpha$-L-fucosidase was detected in one of the few studies concerning the degradation of these glycoconjugates in $T$. cruzi, although the existence of galactosidases, glucosidases and mannosidases has been described (12, 13).

The enzyme $\alpha$-L-fucosidase is a ubiquitous glycosidase in eukaryotic cells, usually found as a soluble component within the lysosome, and acting as an acid hydrolase in the degradation of fucose-containing glycoconjugates. The enzyme is also present in body fluids and in the plasma membrane, as reported for sperm cells $(14,15)$ or human erythrocytes (16).

The presence of $\alpha$-L-fucosidase in epimastigote and trypomastigote forms of $T$. cruzi is demonstrated here using biochemical and immunological approaches. The enzyme has a neutral $\mathrm{pH}$ optimum and is partially localized on the plasma membrane of both forms of the parasite.

\section{Material and Methods}

\section{Parasites}

Epimastigote forms of T. cruzi, CL-14 strain (17) kindly supplied by Dr. E. Chiari, were grown in liver infusion tryptose (LIT) medium supplemented with $10 \%$ fetal calf serum $(\mathrm{FCS})$, at $28^{\circ} \mathrm{C}(18,19)$. Metacyclic trypomastigote forms of $T$. cruzi, Y strain, were obtained in a mixture of $55 \%$ Grace medium, $20 \%$ LIT medium and $25 \%$ preconditioned LIT medium supplemented with $10 \%$ FCS at $28^{\circ} \mathrm{C}$. Trypomastigotes of $T$. cruzi were obtained by infecting LLC-MK ${ }_{2}$ tissue-cultured cells, as described (20).

\section{Preparation of cell extract}

Cells were harvested by centrifugation and washed three times with phosphate-buff- ered saline (PBS), pH 7.2 (5,000 g, $10 \mathrm{~min}$ at $\left.4^{\circ} \mathrm{C}\right)$. The pellet was resuspended in PBS (1 x $10^{9}$ cells $/ \mathrm{ml}$ ) containing $1 \mathrm{mM}$ phenylmethylsulfonyl fluoride and $1 \mathrm{mMN}$ - $p$-tosylL-lysine chloromethyl ketone, and the parasites were immediately lysed by sonication ( $3 \times 30 \mathrm{~s}$ in ice). The insoluble material was removed by centrifugation $(10,000 \mathrm{~g}, 15 \mathrm{~min}$ at $4^{\circ} \mathrm{C}$ ) and the supernatant employed in the assays. The protein content was determined as described (21).

\section{Tunicamycin treatment of Trypanosoma cruzi}

Parasites $\left(5 \times 10^{8}\right)$ were incubated with or without $10 \mu \mathrm{g}$ of tunicamycin in $10 \mathrm{ml}$ of methionine-free Dulbecco modified Eagles' medium supplemented with $2 \%$ FCS. After $3 \mathrm{~h}, 300 \mu \mathrm{Ci}$ of $\left[{ }^{35} \mathrm{~S}\right]-$ methionine was added and the incubation continued for another $2 \mathrm{~h}$ and $30 \mathrm{~min}$. The medium was removed by centrifugation and the cells were washed with PBS, as described above. All incubations were carried out at $28^{\circ} \mathrm{C}$ for epimastigotes and at $37^{\circ} \mathrm{C}$ for trypomastigotes.

\section{Enzymatic assays}

Extracts were prepared as described above. The extract corresponding to $5 \times 10^{9}$ epimastigotes was centrifuged at $80,000 \mathrm{~g}$ for $2 \mathrm{~h}$ at $4^{\circ} \mathrm{C}$. The supernatant was separated and the pellet resuspended in $66 \mathrm{mM}$ $\mathrm{NaH}_{2} \mathrm{PO}_{4} / \mathrm{Na}_{2} \mathrm{HPO}_{4}$ buffer, $\mathrm{pH}$ 7.0, or treated for $60 \mathrm{~min}$ with $1 \mathrm{M} \mathrm{NaCl}$. The material solubilized with $\mathrm{NaCl}$ was separated by centrifugation at $80,000 \mathrm{~g}$ for $2 \mathrm{~h}$ at $4^{\circ} \mathrm{C}$ and the pellet was resuspended and dialyzed against $66 \mathrm{mM} \mathrm{NaH}{ }_{2} \mathrm{PO}_{4} / \mathrm{Na}_{2} \mathrm{HPO}_{4}$ buffer, $\mathrm{pH}$ 7.0, for $18 \mathrm{~h}$ at $4^{\circ} \mathrm{C} . \alpha$-L-fucosidase activity was determined by measuring the amount of $p$ nitrophenol released by the hydrolysis of $p$ nitrophenyl- $\alpha$-L-fucopyranoside (Sigma, St. Louis, MO, USA), as described $(22,23)$. The reaction mixture containing $0.5 \mathrm{mM} p$-nitrophenyl- $\alpha$-L-fucopyranoside in $66 \mathrm{mM}$ $\mathrm{NaH}_{2} \mathrm{PO}_{4} / \mathrm{Na}_{2} \mathrm{HPO}_{4}$ buffer, $\mathrm{pH}$ 7.0, and the 
desired amount of protein was incubated for $60 \mathrm{~min}$ at $37^{\circ} \mathrm{C}$. The reaction was stopped by the addition of $1 \mathrm{ml}$ of $0.25 \mathrm{M} \mathrm{Na}_{2} \mathrm{CO}_{3} /$ $\mathrm{NaHCO}_{3}$ and absorbance was read at 410 $\mathrm{nm}$. The amount of $p$-nitrophenol was calculated using the molar extinction coefficient of the $p$-nitrophenolate ion, $1.75 \times 10^{4} \mathrm{M}^{-1}$ $\mathrm{cm}^{-1}$. One enzyme unit (U) is defined as $\mu$ mol of $p$-nitrophenolate ion formed per minute and specific activity is defined as $\mathrm{U} /$ $\mathrm{mg}$ protein. Alternatively, the amount of Lfucose as the reaction product was determined by high-performance liquid chromatography for carbohydrates using a CarboPac PA-100 anion exchange column (Dionex Co., Sunnyvale, CA, USA).

The stability of the $\alpha$-L-fucosidase activity was determined after storage of the enzyme at $4{ }^{\circ} \mathrm{C}$ or $-20^{\circ} \mathrm{C}$ in the presence of $50 \%$ glycerol, $50 \mu \mathrm{g} / \mathrm{ml}$ bovine serum albumin (BSA) or $2 \mathrm{mM}$ B-mercaptoethanol. The inactivation plot was obtained by preincubation of the epimastigote extract at $28^{\circ}$ or $37^{\circ} \mathrm{C}$ for different periods of time followed by the standard enzymatic assay. The optimal $\mathrm{pH}$ for $\alpha$-L-fucosidase was determined in $66 \mathrm{mM}$ sodium acetate buffer, $\mathrm{pH}$ 5.0-6.5, or $66 \mathrm{mM} \mathrm{NaH} \mathrm{PO}_{4} / \mathrm{Na}_{2} \mathrm{HPO}_{4}$ buffer, $\mathrm{pH}$ 7.0-8.0. Standard assay conditions, $\mathrm{pH} 7.0$, were used to determine the optimal temperature of the reaction.

\section{Gel electrophoresis and immunoblotting}

Samples were submitted to SDS-PAGE ( $0.1 \%$ SDS, $9 \%$ polyacrylamide) as described (24). After electrophoresis, the gels were fixed and stained with $0.2 \%$ Coomassie blue (25) or with the $\mathrm{AgNO}_{3}$ stain (26). For immunoblotting, the gels were incubated in 25 $\mathrm{mM}$ Tris/192 mM glycine and $40 \%$ methanol for $15 \mathrm{~min}$ and the proteins were transferred onto a nitrocellulose membrane at 50 volts for $18 \mathrm{~h}$ at $4^{\circ} \mathrm{C}(27)$. After blockage with $50 \mathrm{mM}$ TBS- $0.03 \%$ Tween $20, \mathrm{pH} 8.0$, and $1 \% \mathrm{BSA}$, the membrane was incubated with mouse anti-bovine epididymis $\alpha$-L- fucosidase polyclonal antibodies in the same buffer. After washing, the blot was incubated with horseradish peroxidase-conjugated anti-mouse IgG and developed with an ECL Western blot chemiluminescense kit (AmershamBioscience, Piscataway, NJ, USA).

Antibodies. Anti-bovine epididymis $\alpha$ L-fucosidase antibodies were obtained by injecting $\mathrm{BALB} / \mathrm{c}$ mice with the gel band containing the enzyme after submitting a commercial preparation (Oxford Glycosystems, Abingdon, Oxon, England) to SDSPAGE. The band was sliced in PBS, sonicated (30 s, 10 times) and mixed with Freund's adjuvant before injection. The specificity of the antibodies was confirmed by Western blot analysis against commercial $\alpha$-L-fucosidase.

\section{Immunoprecipitation}

Extracts from epimastigotes and trypomastigotes previously labeled with $\left[{ }^{35} \mathrm{~S}\right]-$ methionine were preincubated with $50 \mu \mathrm{l}$ Sepharose-Protein A (AmershamBioscience) in PBS. The samples were centrifuged and the supernatants incubated with $50 \mu$ l Sepharose-Protein A and $10 \mu \mathrm{l}$ of anti-bovine epididymis $\alpha$-L-fucosidase at $4^{\circ} \mathrm{C}$. After overnight incubation, the samples were exhaustively washed with $100 \mathrm{mM}$ Tris, $\mathrm{pH} \mathrm{8.6,}$ $300 \mathrm{mM} \mathrm{NaCl}, 10 \mathrm{mM}$ EDTA, $0.05 \%$ Nonidet P-40, $1 \% \mathrm{BSA}$, and $0.02 \% \mathrm{NaN}_{3}$ before the addition of SDS sample buffer $(25$ mM Tris-HCl, pH 6.8, 38\% glycerol, $0.2 \mathrm{M}$ EDTA, 2\% SDS, $4 \%$ ß-mercaptoethanol, and bromophenol blue).

\section{Indirect immunofluorescence}

Epimastigotes and trypomastigotes were washed three times in PBS, pH 7.2, and fixed in $2 \%$ paraformaldehyde in PBS, $\mathrm{pH} 7.2$, for $1 \mathrm{~h}$ at $4^{\circ} \mathrm{C}$. The cells were incubated with anti-bovine epididymis $\alpha$-L-fucosidase polyclonal antibodies at the desired dilution 
(1:500) for $30 \mathrm{~min}$ at $37^{\circ} \mathrm{C}$, washed in PBS and incubated with fluorescein-conjugated anti-mouse $\mathrm{IgG}$ (Sigma) for $30 \mathrm{~min}$ at $37^{\circ} \mathrm{C}$.

Electron microscopy. Parasites were washed in PBS and fixed in a solution of $0.5 \%$ glutaraldehyde, $4 \% p$-formaldehyde, and $0.2 \%$ picric acid in $0.1 \mathrm{M}$ sodium cacodylate buffer, $\mathrm{pH}$ 7.4. After $90 \mathrm{~min}$, the cells were washed in $50 \mathrm{mM}$ glycine in $0.1 \mathrm{M}$ sodium cacodylate buffer, $\mathrm{pH} 7.4$, embedded in $10 \%$ gelatin, cut into $1-\mathrm{mm}^{3}$ pieces, and maintained overnight at $4^{\circ} \mathrm{C}$ in $2.3 \mathrm{M}$ sucrose. After freezing in liquid nitrogen, the samples were dehydrated with methanol by cryosubstitution at $-90^{\circ} \mathrm{C}$ for $48 \mathrm{~h}$ and embedded in Lowicryl HM20 resin at $-45^{\circ} \mathrm{C}$. Ultrathin sections were collected on 300mesh nickel grids and incubated for $30 \mathrm{~min}$ with $50 \mathrm{mM}$ glycine in PBS, followed by 30 min in PBS containing $0.1 \%$ BSA. The material was incubated for $16 \mathrm{~h}$ at $4{ }^{\circ} \mathrm{C}$ in the same medium containing anti-bovine epididymis $\alpha$-L-fucosidase serum, washed with PBS$1 \%$ BSA and incubated for $60 \mathrm{~min}$ at room temperature with protein A coupled to 10$\mathrm{nm}$ colloidal gold particles. The grids were washed, stained with $2 \%$ uranyl acetate, and observed with a Jeol 1200 EXII transmission electron microscope.

Figure 1. Reactivity of anti- $\alpha$-Lfucosidase antibodies with epimastigote and trypomastigote forms of Trypanosoma cruzi. The reactivity was confirmed by indirect immunofluorescence with p-formaldehyde-fixed parasites and visualized under a confocal microscope. A, Epimastigotes; $B$, trypomastigotes. 1, Phasecontrast microscopy; 2, fluorescence microscopy.

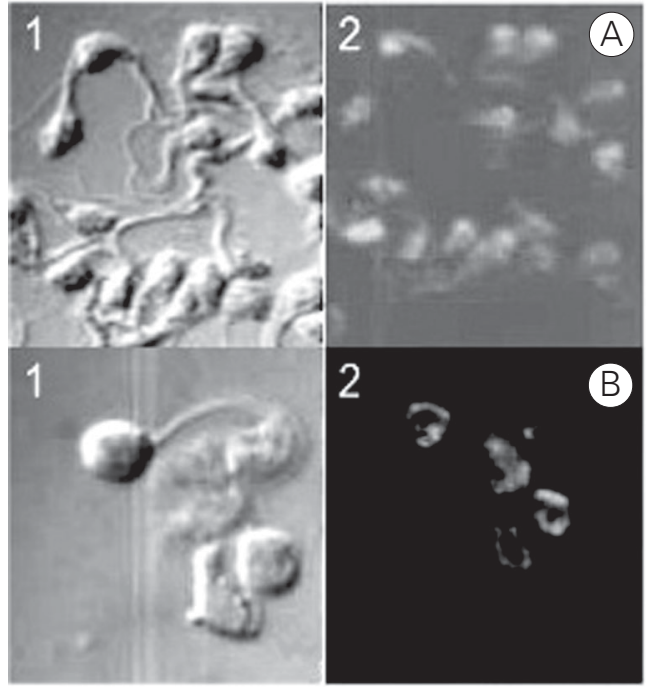

\section{Results}

Anti- $\alpha$-L-fucosidase antibodies react with epimastigote and trypomastigote forms of Trypanosoma cruzi

Antibodies raised against a commercial preparation of $\alpha$-L-fucosidase were employed to check for the presence of the enzyme in $T$. cruzi, since data from the literature showed an almost undetectable amount of enzymatic activity in extracts of the parasite. Epimastigote and trypomastigote forms of $T$. cruzi presented intense reactivity with the anti-fucosidase antibodies by indirect immunofluorescence (Figure 1). No fluorescence was observed when serum from a nonimmunized mouse or PBS was used as negative controls. When fucosidase was located by immunocytochemistry at the ultrastructural level, a strong labeling was observed in epimastigotes over the posterior region of the cell, apparently associated with membranes and also widespread on the plasma membrane (Figure 2A). In comparison, a less intense labeling was detected in the perinuclear region with poor plasma membrane labeling when trypomastigotes were analyzed (Figure 2B).

Activity of $\alpha$-L-fucosidase in different developmental stages of Trypanosoma cruzi

Extracts of T. cruzi epimastigotes and trypomastigotes hydrolyze the synthetic substrate $p$-nitrophenyl- $\alpha$-L-fucopyranoside. In spite of a low enzymatic activity detected in both stages, a higher specific activity was measured in epimastigote extracts (0.03 $\mathrm{U} / \mathrm{mg}$ protein) when compared to trypomastigotes $(0.002 \mathrm{U} / \mathrm{mg}$ protein). For this reason epimastigote extracts were employed in most of the experiments. The activity of $\alpha$-Lfucosidase in epimastigotes was proportional to the amount of protein (data not shown). A significant variability was observed among different preparations (Table 1) which was 
independent of the cell density of the culture or the amount of metacyclic trypomastigotes that appear by spontaneous differentiation from epimastigotes. Metacyclic trypomastigotes also showed a low enzymatic activity (0.015 $\mathrm{U} / \mathrm{mg}$ protein).

\section{Stability and kinetic parameters of $\alpha$-L-fucosidase from epimastigotes}

Preliminary experiments indicated that $\alpha$-L-fucosidase from epimastigote extracts and from $\mathrm{NaCl}$-solubilized membrane fractions (see below) were unstable when stored at $4^{\circ}$ or $-20^{\circ} \mathrm{C}$ in the presence or absence of $50 \%$ glycerol, $50 \mu \mathrm{g} / \mathrm{ml} \mathrm{BSA}$ or $2 \mathrm{mM} \mathrm{B-}$ mercaptoethanol (data not shown). The enzyme is inhibited by Tris buffer, as described for other fucosidases (23). For this reason, all the enzymatic assays were performed with fresh extracts.

Incubation for 60 min was used for most of the experiments (Figure 3 ) at either $28^{\circ}$ or $37^{\circ} \mathrm{C}$ due to the low amount of activity of the enzyme. Optimum temperature was established as $37^{\circ} \mathrm{C}$ (data not shown). The enzyme showed maximal activity at neutral $\mathrm{pH}(\mathrm{pH}$ 6.0-7.5) and lost activity at acidic or basic $\mathrm{pH}$ (Figure 4). When the reaction product was analyzed by anion-exchange chromatography, a peak coincident with L-fucose was also observed when the reaction was carried out at $\mathrm{pH}$ 5.0, although much less intense in comparison to the peak observed at $\mathrm{pH} 7.0$ (data not shown). Even though fresh extracts were employed in all experiments, a rapid inactivation of $\alpha$-L-fucosidase was observed. Figure 5 shows the decrease of the enzymatic activity measured after preincubation of epimastigote extracts for different periods of time at $28^{\circ}$ or $37^{\circ} \mathrm{C}$ prior to the standard enzyme assay. The enzyme preparation lost $50 \%$ of its activity after $2 \mathrm{~h}$ of preincubation and no trace activity was detected after $4 \mathrm{~h}$. Addition of glycerol or $\mathrm{B}$ mercaptoethanol during preincubation did not protect the enzyme activity from inactivation.
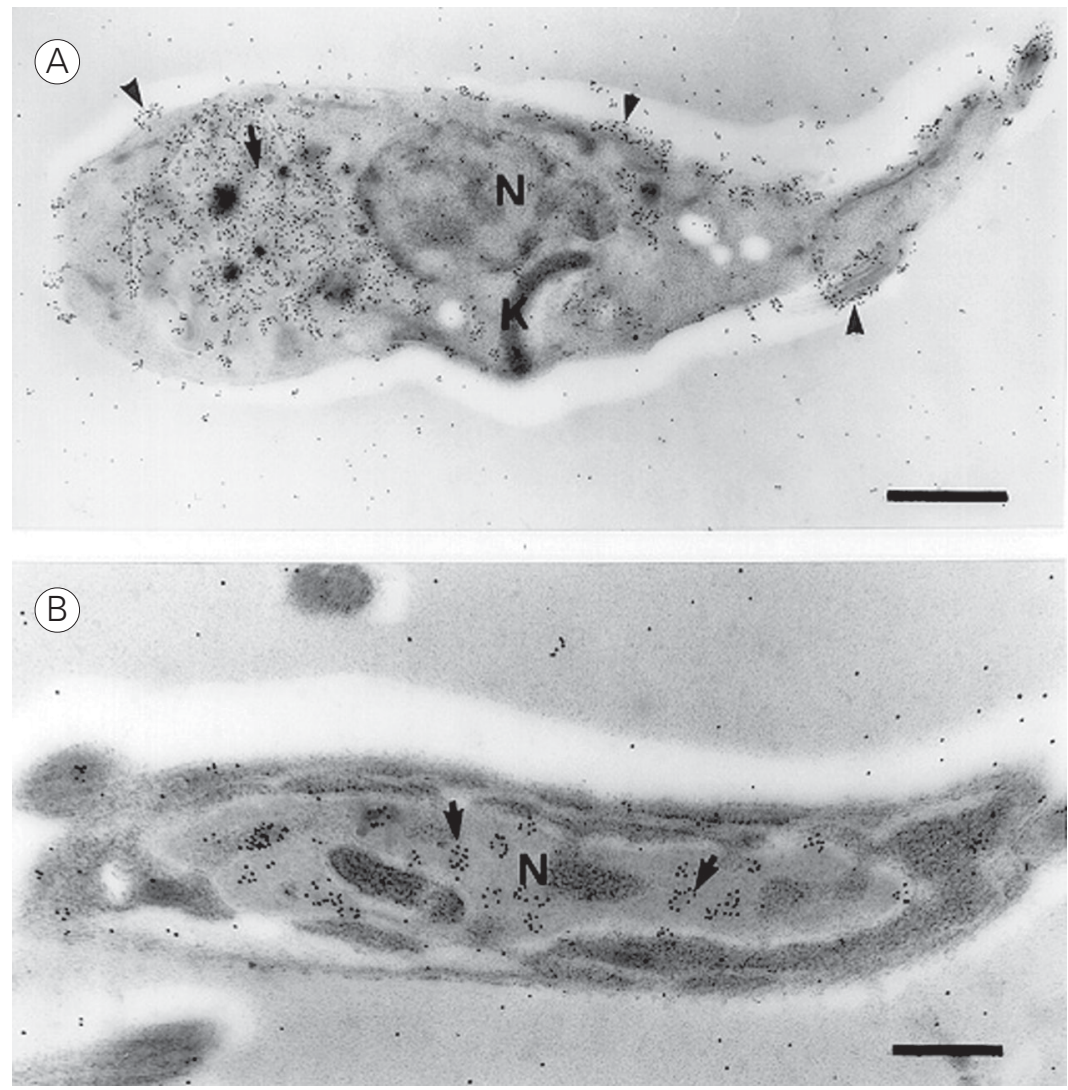

Figure 2. Immunocytochemical localization of $\alpha$-L-fucosidase in Trypanosoma cruzi. UItrathin sections of epimastigote (A) and trypomastigote (B) forms of $T$. cruzi were first incubated with anti- $\alpha$-L-fucosidase and then with gold-labeled protein A. Gold particles are seen in the cytoplasm (arrows) and on the surface of the plasma membrane (arrowheads). $\mathrm{N}$ : nucleus; K: kinetoplast. Bar: $1 \mu \mathrm{m}$.

Table 1. Activity of $\alpha$-L-fucosidase in different preparations of Trypanosoma cruzi epimastigote extracts

\begin{tabular}{lcrc} 
Experiment & Cell density & $\begin{array}{c}\text { Metacyclic } \\
\text { forms (\%) }\end{array}$ & $\begin{array}{c}\text { Specific } \\
\text { activity }\end{array}$ \\
\hline 1 & 120 & 8.0 & 0.04 \\
2 & 110 & 7.0 & 0.10 \\
3 & 112 & 10.0 & 0.16 \\
4 & 130 & 8.0 & 0.03 \\
5 & 90 & 7.5 & 0.23 \\
6 & 100 & 8.0 & 0.04 \\
\hline
\end{tabular}

All incubations were performed for $60 \mathrm{~min}$. Cell density is the number of parasites $\left(10^{6} / \mathrm{ml}\right)$ in culture. All samples correspond to parasites in the stationary phase of growth. Specific activity is reported as U/mg protein. 
Figure 3. $\alpha$-L-fucosidase activity as a function of incubation time. An epimastigote extract 10.4 $\mathrm{mg}$ ) was incubated with $p$-nitrophenyl- $\alpha$-L-fucopyranoside for the times indicated on the abscissa in $66 \mathrm{mM} \mathrm{NaH}_{2} \mathrm{PO}_{4} /$ $\mathrm{Na}_{2} \mathrm{HPO}_{4}$ buffer, pH 7.0.

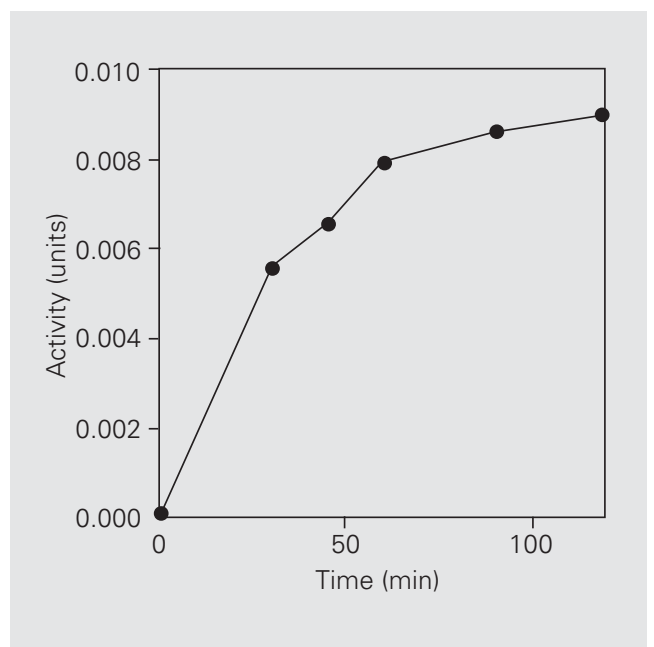

Figure 4. Effect of $\mathrm{pH}$ on the activity of epimastigote $\alpha$-L-fucosidase. The enzymatic assay was carried out as described in Material and Methods using $0.4 \mathrm{mg}$ protein of an epimastigote extract.

Figure 5. Inactivation of $\alpha$-Lfucosidase with time. Epimastigote extracts were preincubated at $28^{\circ} \mathrm{C}$ (squares) or $37^{\circ} \mathrm{C}$ (circles) for the periods of time shown on the abscissa. Activity was measured by the standard enzymatic assay.
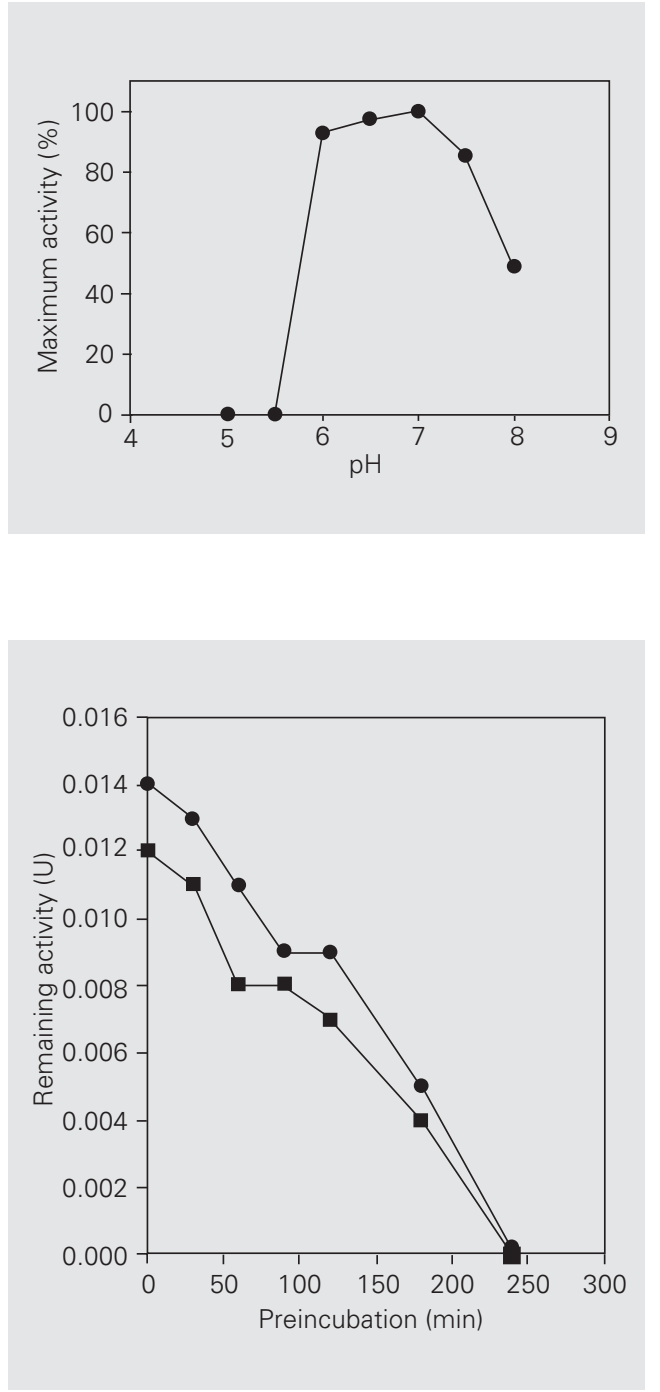

Table 2. Association of $\alpha$-L-fucosidase from Trypanosoma cruzi with membrane fractions.

\begin{tabular}{lcc}
\hline Fraction & $\begin{array}{r}\text { Total } \\
\text { units }\end{array}$ & $\begin{array}{r}\text { Specific } \\
\text { activity }\end{array}$ \\
\hline Extract & 0.24 & 0.05 \\
$80,000 \mathrm{~g}$ pellet & 0.12 & 0.31 \\
$1 \mathrm{M} \mathrm{NaCl}$ insoluble fraction & 0.01 & 0.02 \\
$1 \mathrm{M} \mathrm{NaCl}$ solubilized fraction & 0.10 & 0.12 \\
$1 \%$ Triton X-100 insoluble & 0.03 & 0.04 \\
$\quad$ fraction & & \\
$\begin{array}{l}\text { 1\% Triton X-100 solubilized } \\
\text { fraction }\end{array}$ & 0.08 & 0.14 \\
\hline
\end{tabular}

Total units $=\mu \mathrm{mol} p$-nitrophenolate released $/ \mathrm{min}$. Specific activity is reported as $\mathrm{U} / \mathrm{mg}$ protein.

\section{Characterization of $\alpha$-L-fucosidase from epimastigotes}

Extracts of epimastigotes were centrifuged at $80,000 \mathrm{~g}$. Half of the total $\alpha$-Lfucosidase activity was detected in the pellet, with a 6-fold increase in specific activity (Table 2). Treatment of the pellet with $1 \%$ Triton X-100 or $1 \mathrm{M} \mathrm{NaCl}$ solubilized 66 and $83 \%$ of the enzymatic activity, respectively, suggesting that the protein is weakly bound to membranes. An enrichment of a $50-\mathrm{kDa}$ polypeptide in the $\mathrm{NaCl}$-solubilized fraction was demonstrable by SDS-PAGE (Figure 6A), which is compatible with the molecular mass described for the monomers of $\alpha$-L-fucosidases (28). Moreover, anti- $\alpha$ L-fucosidase antibodies immunoprecipitated a 50-kDa polypeptide from total extracts of $\left[{ }^{35} \mathrm{~S}\right]$-methionine-labeled epimastigotes and a 45-50-kDa protein doublet from the NaClsolubilized fraction as indicated by SDSPAGE (Figure 6B). A 50-kDa polypeptide was also immunoprecipitated from $\left[{ }^{35} \mathrm{~S}\right]-$ methionine-labeled trypomastigotes (data not shown). The specificity of the antibody was confirmed by immunoprecipitation of the total extract or $1 \mathrm{M} \mathrm{NaCl}$-treated membrane fractions from epimastigotes with anti- $\alpha$-Lfucosidase, followed by the standard enzymatic assay. In both cases, the antibodies 
immunoprecipitated a protein with a very low, but detectable fucosidase activity.

Since $\alpha$-L-fucosidases described for different organisms are glycoproteins, the enzyme from $T$. cruzi was checked for the presence of carbohydrates. The presence of $\mathrm{N}$-linked oligosaccharides was suggested by the 5-kDa decrease in the molecular mass of the enzyme immunoprecipitated from epimastigotes labeled with $\left[{ }^{35} \mathrm{~S}\right]$-methionine in the presence of tunicamycin (Figure 7).

\section{Discussion}

The aim of the present report was to unequivocally establish the presence of $\alpha$-Lfucosidase in $T$. cruzi. Immunocytochemical techniques and detection of enzymatic activity were used to demonstrate that at least $50 \%$ of the enzyme is associated with the cytoplasmic and plasma membranes. Although most of the $\alpha$-L-fucosidase activity of virtually all mammalian tissues is in the soluble fraction, membrane-associated $\alpha$-Lfucosidase has been described in rat testis and epididymal spermatozoa $(14,29)$, in human sperm plasma membrane (15), and in human erythrocyte membranes (16).

Gel electrophoresis analysis of the $1 \mathrm{M}$ $\mathrm{NaCl}$-solubilized membranes from epimastigotes showed a broad band with apparent molecular mass of $50 \mathrm{kDa}$ that was recognized by the anti- $\alpha$-L-fucosidase antibody. In some preparations two bands of 45 and 50 $\mathrm{kDa}$ were visualized that probably corresponded to distinct isoforms or to different contents of carbohydrate. Isoforms of $\alpha$-Lfucosidase with distinct $\mathrm{pI}$ and $\mathrm{pH}$ optima have been described in the literature $(15,29)$. The $\alpha$-L-fucosidase from the membrane fraction of epimastigotes has a neutral $\mathrm{pH}$ optimum ( $\mathrm{pH}$ 6.0-7.5), having no activity at acidic $\mathrm{pH}$, in contrast to $\alpha$-L-fucosidases isolated from lysosomes. A more neutral $\mathrm{pH}$ optimum was described for $\alpha$-L-fucosidases from Corynebacterium, pH 8.5 (30), Helicobacter pylori, $\mathrm{pH}$ 7.0, (31), Trichomonas

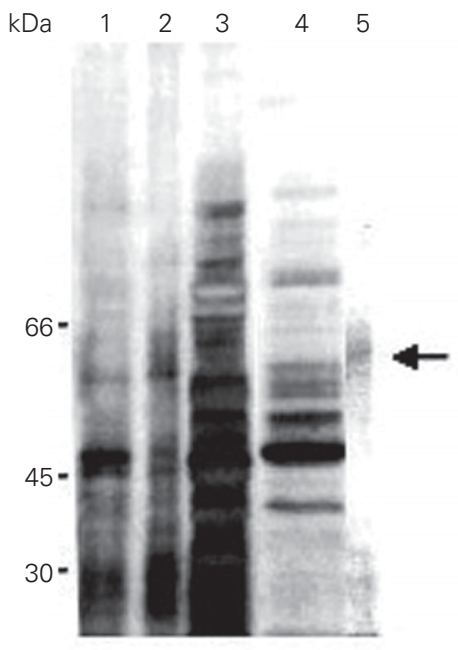

A

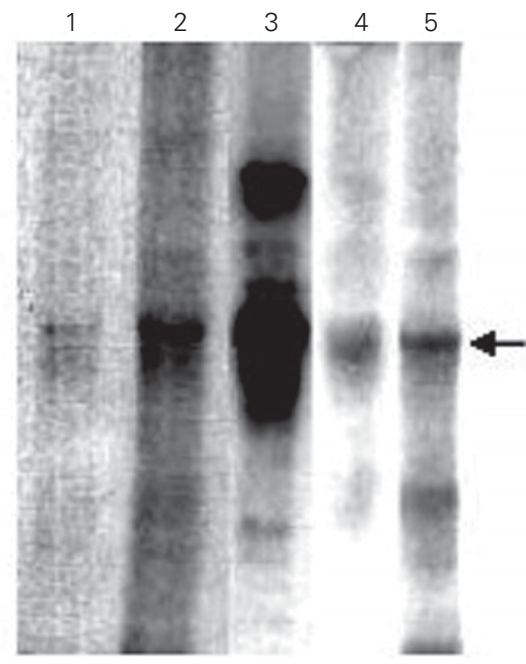

B
Figure 6. SDS-PAGE of $\alpha$-L-fucosidase from Trypanosoma cruzi epimastigotes. $A$, The $80,000 \mathrm{~g}$ pellet of the epimastigote extract was treated with $1 \mathrm{M} \mathrm{NaCl}$ and subjected to another $80,000 \mathrm{~g}$ centrifugation. Aliquots from the fractions were concentrated, submitted to SDS-PAGE and stained with Coomassie blue. B, Identical fractionation was performed using [ ${ }^{35}$ S]-methionine-labeled epimastigotes followed by immunoprecipitation with anti- $\alpha$ L-fucosidase antibodies and autoradiography. Lane 1, Total extract; lane 2, 80,000 g pellet; lane 3, 80,000 g supernatant; lane 4, insoluble $1 \mathrm{M} \mathrm{NaCl}$-treated 80,000 g fraction; lane 5, soluble $1 \mathrm{M} \mathrm{NaCl}$-treated $80,000 \mathrm{~g}$ fraction. The arrow on the right side of each set of gels indicates the position of a molecular mass of $50 \mathrm{kDa}$.

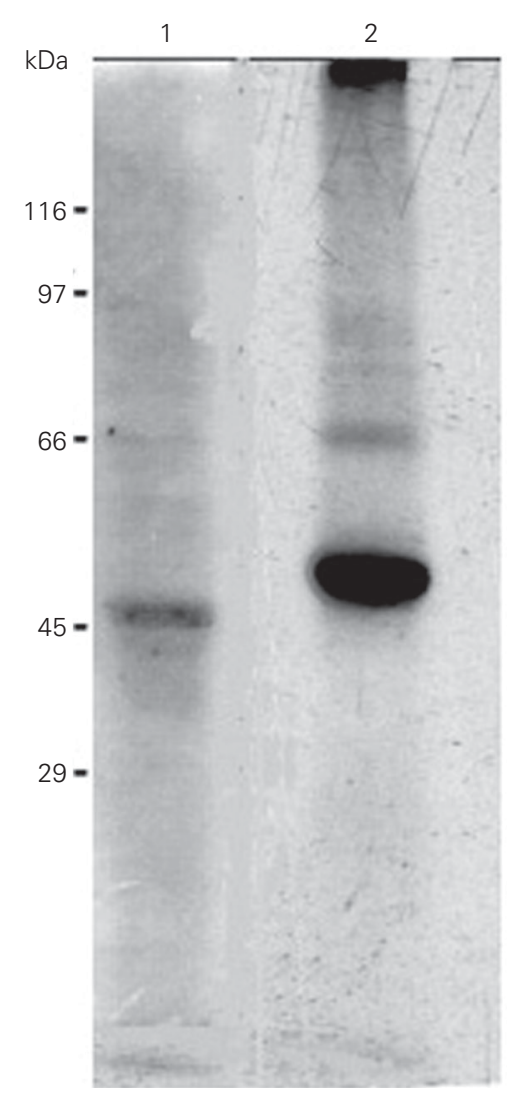

Figure 7. Glycoprotein nature of the $\alpha$-L-fucosidase from Trypanosoma cruzi. Extracts of epimastigotes metabolically labeled in the presence (lane 1) or absence (lane 2) of $10 \mu \mathrm{g} / \mathrm{ml}$ tunicamycin were immunoprecipitated with anti- $\alpha$-L-fucosidase and subjected to SDSPAGE and autoradiography. 
foetus, pH 7.0 (32), and for the enzymes from rat sperm and erythrocytes $(14,16)$.

Overall, the results reported here provide strong evidence for the presence of a neutral $\alpha$-L-fucosidase in T. cruzi epimastigotes and trypomastigotes. The immunolabeling experiments suggest that the enzyme is highly represented in both parasite stages, and particularly abundant in epimastigotes in spite of the low enzymatic activities detected. The instability of the enzyme may explain this apparent contradiction, in addition to the possibility that $p$-nitrophenyl- $\alpha$-L-fucopyranoside might not be an adequate substrate for the T. cruzi enzyme, as was the case for fucosidases from Trichomonas foetus that could not be detected using nitrophenyl-sug- ars (cf. Ref. 13). Since no activity was also detected in epimastigotes from $T$. cruzi when 4-methylumbelliferyl- $\alpha$-L-fucoside was employed instead the $p$-nitrophenyl- $\alpha-\mathrm{L}$ fucopyranose (data not shown), a study involving natural substrates will be required.

The failure to detect $\alpha$-L-fucosidase in epimastigotes or even the exceedingly low activities reported for blood trypomastigotes by different groups $(12,33)$ is, most likely, a reflection of the enzyme's lability under the assay conditions used. Nevertheless, despite the inherent difficulties in measuring the enzyme activity, the presence of L-fucosidase on the plasma membrane of $T$. cruzi raises the provocative question of a possible role of the enzyme in glycoconjugate function.

\section{References}

1. Ferguson MAJ (1999). The structure, biosynthesis and functions of glycosylphosphatidylinositol anchors, and the contributions of trypanosome research. Journal of Cell Science, 112: 2799-2809.

2. Snary D, Ferguson MAJ, Scott MT \& Allen AK (1981). Cell surface antigens of Trypanosoma cruzi; use of monoclonal antibodies to identify and isolate a specific glycoprotein. Molecular and Biochemical Parasitology, 3: 343-358.

3. Ferguson MAJ, Allen AK \& Snary D (1983). Studies on the structure of a phosphoglycoprotein from the parasitic protozoan Trypanosoma cruzi. Biochemical Journal, 213: 313-320.

4. Sher A \& Snary D (1982). Specific inhibition of morphogenesis of Trypanosoma cruzi by a monoclonal antibody. Nature, 300: 639-642.

5. Katzin AM \& Colli W (1983). Lectin receptors in Trypanosoma cruzi, an $\mathrm{N}$-acetyl-D-glucosamine-containing surface glycoprotein specific for the trypomastigote stage. Biochimica et Biophysica Acta, 727: 403-417.

6. Couto AS, Katzin AM, Colli W \& Lederkremer RM (1987). Sialic acid in a complex oligosaccharide chain of the Tc-85 surface glycoprotein from the trypomastigote stage of Trypanosoma cruzi. Molecular and Biochemical Parasitology, 26: 145-154.

7. Couto AS, Gonçalves MF, Colli W \& Lederkremer RM (1990). The Nlinked carbohydrate chain of the 85-kilodalton glycoprotein from Trypanosoma cruzi trypomastigotes contains sialyl, fucosyl, and galactosyl ( $\alpha$ 1-3) galactose units. Molecular and Biochemical Parasitology, 39: 101-110.

8. Alves MJM, Abuin G, Kuwajima VY \& Colli W (1986). Partial inhibition of trypomastigote entry into cultured cells by monoclonal antibodies against a surface glycoprotein of Trypanosoma cruzi. Molecular and Biochemical Parasitology, 21: 75-82.

9. Giordano R, Fouts DL, Tewari D, Colli W, Manning JE \& Alves MJM (1999). Cloning of a surface membrane glycoprotein specific for the infective form of Trypanosoma cruzi having adhesive properties to laminin. Journal of Biological Chemistry, 274: 3461-3468.
10. Magdesian $M H$, Giordano $R$, Ulrich $H$, Juliano MA, Juliano $L$, Schumacher RI, Colli W \& Alves MJM (2001). Infection by Trypanosoma cruzi: Identification of a parasite ligand and its host cell receptor. Journal of Biological Chemistry, 276: 19382-19389.

11. Haynes PA, Ferguson MAJ \& Cross GAM (1996). Structural characterization of novel oligosaccharides of cell-surface glycoproteins of Trypanosoma cruzi. Glycobiology, 6: 869-878.

12. Avila JL, Casanova MA, Avila A \& Bretaña A (1979). Acid and neutral hydrolases in Trypanosoma cruzi. Characterization and assay. Journal of Protozoology, 26: 304-311.

13. Connaris S \& Greewell P (1997). Glycosidases in mucin-dwelling protozoans. Glycoconjugate Journal, 14: 879-882.

14. Avilés M, Abascal I, Martínez-Menárguez JAA, Castells MT, Skalaban SR, Ballesta J \& Alhadeff JA (1996). Immunocytochemical localization and biochemical characterization of a novel plasma membraneassociated, neutral $\mathrm{pH}$ optimum $\alpha$-L-fucosidase from rat testis and epididymal spermatozoa. Biochemical Journal, 318: 821-831.

15. Alhadeff JA, Khunsook S, Choowongkomon K, Baney T, Heredia V, Tweedie A \& Ban B (1999). Characterization of human semen $\alpha$-Lfucosidases. Molecular Human Reproduction, 5: 809-815.

16. Goi G, Bairati C, Massaccesi L, Lovagnini A, Lombardo A \& Tettamanti G (2000). Membrane anchoring and surface distribution of glycohydrolases of human erythrocyte membrane. FEBS Letters, 473: 89-94.

17. Brener Z \& Chiari E (1963). Variações morfológicas observadas em diferentes amostras de Trypanosoma cruzi. Revista do Instituto de Medicina Tropical de São Paulo, 5: 220-224.

18. Camargo EP (1964). Growth and differentiation in Trypanosoma cruzi. I. Origin of metacyclic trypanosomes in liquid media. Revista do Instituto de Medicina Tropical de São Paulo, 6: 93-100.

19. Castellani O, Ribeiro LV \& Fernandes JF (1967). Differentiation of Trypanosoma cruzi in culture. Journal of Protozoology, 14: 447-451.

20. Andrews NW \& Colli W (1982). Adhesion and interiorization of 
Trypanosoma cruzi in mammaliam cells. Journal of Protozoology, 29: 264-269.

21. Bradford M (1976). A rapid and sensitive method for the quantitation of microgram quantities of protein utilizing the principle of proteindye binding. Analytical Biochemistry, 72: 248-256.

22. Hall CL, Liebars I, Natalli PD \& Neufeld EF (1978). $\alpha$-L-Fucosidase. Methods in Enzymology, 50: 453-463.

23. Levvy GA \& McAllan A (1961). Mammalian fucosidases. Biochemical Journal, 80: 435-439.

24. Laemmli UK (1970). Cleavage of structural proteins during the assembly of the head of bacteriophage T4. Nature, 227: 680-685.

25. Peterson GL (1983). Coomassie blue dye binding protein quantification method. Methods in Enzymology, 91: 108-110.

26. Morrissey JH (1981). Silver stain for proteins in polyacrylamide gels: a modified procedure with enhanced uniform sensitivity. Analytical Biochemistry, 117: 307-310.

27. Towbin H, Stahelin T \& Gordon J (1979). Electrophoretic transfer of proteins from polyacrylamide gels to nitrocellulose sheets: Procedures and some applications. Proceedings of the National Academy of Sciences, USA, 76: 4350-4354.

28. Butters TD, Scudder P, Rotsaert J, Petursson S, Fleet GWJ,
Willenbrock FW \& Jacob GS (1991). Purification to homogeneity of Charonia lampas $\alpha$-fucosidase by using sequential ligand affinity chromatography. Biochemical Journal, 279: 189-195.

29. Abascal I, Skalaban SR, Grimm KM, Aviles M, Martianez-Menarguez JA, Castells MT, Ballesta J \& Alhadeff JA (1998). Alteration of the isoform composition of plasma-membrane-associated rat sperm $\alpha$ L-fucosidase during late epididymal maturation: comparative characterization of the acidic and neutral isoforms. Biochemical Journal, 333: 201-207.

30. Fukuda M \& Kobata A (1993). Glycobiology: A Practical Approach. IRL Press, New York, NY, USA.

31. Dwarakanath AD, Tsai HH, Sunderland D, Hart CA, Figura N, Crabtree JE \& Rhodes JM (1995). The production of neuraminidase and fucosidase by Helicobacter pylori - Their possible relationship to pathogenicity. FEMS Immunology and Medical Microbiology, 12: 213-216.

32. Watkins WM (1959). Enzymes of Trichomonas foetus. Biochemical Journal, 71: 261-274.

33. Steiger RF, van Hoof F, Bontemps J, Nyssens-Jadin M \& Druetz JE (1979). Acid hydrolases of trypanosomatid flagellates. Acta Tropica, 36: 335-341. 